manufactured goods for goods manufactured in the United States as well as for foodstuffs and raw materials. Before the War American exports of manufactures to Europe were growing more rapidly both in quantity and in relative proportion to our total trade than any other group.

At the same time-and largely making it possible for our exports of manufactured goods to Europe to develop-Europe was sending manufactures to the United States. Whatever interferes with Europe's ability to export manufactures to the United States must inevitably' prevent the United States from exporting to Europe. Europe must depend on manufactured goods to pay her imports. She has comparatively little exportable surplus of other goods. To that degree, therefore, that the manufacturing industry of the United States depends on foreign markets for its full revival, it must largely depend upon the revival of European manufactures.

Europe's ability to buy is largely conditioned by her ability to sell; and she must sell manufactures-the material she has in largest surplus to sell. Since the export of manufactured goods constitutes the most important and the most rapidly growing part of American export trade, and since Europe is and long has been the principal market for those manufactures, there is a vital relation between the development of American trade and American industry to supply that trade and the development of Europe's manufacturing industry.

But not only will the revival of manufacturing industry in Europe stimulate directly the trade of the United States with Europe; it will also stimulate United States trade with other parts of the world. Other sections of the world are depending in large degree for their revival upon the resumption of manufacturing in Europe, making it possible for European countries to buy raw materials and foods which the rest of the world has to sell and upon the selling of which world-prosperity so largely depends.

\title{
America's Prosperity and the Rehabilitation of Europe-Labor's Point of View
}

\author{
By Chester M. Wright \\ Director, Information and Publicity Service, American Federation of Labor
}

$\mathbf{T}$ 10 what precise degree American prosperity is dependent upon the rehabilitation of Europe is, to my mind, of less importance than the finding of those barriers which prevent full and free play of international helpfulness.

We need waste no time in saying that American prosperity is to some extent dependent upon European rehabilitation. It is equally true that
European rehabilitation is to a considerable extent dependent upon the relations, economic and political, between Europe and the United States.

There may have been a time when it was possible to consider material prosperity without regard to other considerations, but that time has passed and there can be no adequate discussion today of material prosperity without discussion of political relations. 
America will not be inclined to reach for material wealth if by so doing she lose her political liberties. America will follow the gospel which teaches that it is of no avail to gain the riches of the world if by so doing America must lose or endanger the soul of her being.

The obstacle that stands in the way of full international economic coöperation is a political obstacle. We may possibly find riches if we care to overlook that obstacle; at least, the international bankers may find riches; the concession hunters may find riches. But if we overlook that obstacle we must forget the principles upon which America is founded; we must sell our national soul. American labor is opposed to that course.

American labor has both an altruistic and an egoistic interest in European rehabilitation. We may expect our imports and our exports to increase as Europe proceeds to recover her normal industrial poise and her normal political existence. Perhaps I should not say "normal" in relation to Europe's political existence, because "normal" in Europe has meant militarism, despotism to a large degree, great armies, great navies, and eternal suspicions, jealousy and intrigue. Those "normal" things must be got rid of.

American labor has shown its interest clearly in international affairs. The public is aware of American labor's support of the League of Nations and its part in forging that great international utility. American labor advocated an international economic conference and labor sponsored the first widely noticed demand for such a conference, long before the cross-breed Genoa Conference was summoned. American labor has participated in many international conferences and it stands ready to participate in any constructive international effort that does not involve treachery to democracy and that does not do violence to fundamental American concepts. American labor has proved its interest in international affairs and its solidarity with European labor. It has proved with equal emphasis its opposition to visionary schemes and revolutionary movements.

\section{Russia, the Obstacle}

The great obstacle in the road today has its roots in Russia. It is a hard fact. Some very earnest persons, some very unbalanced persons, some very greedy persons and some very shrewd and treacherous persons would like us to think to the contrary, but the majority of Americans see the Russian problem substantially as it is, placing no halo on the hideous thing. There is the great obstacle. There is the keystone. True enough, Germany desires to pay as little as possible in reparations, but while in any case it is possible Germany may refrain from an effort to upset the peace of Europe in response to a natural desire to get out from under the load bequeathed to her by the sins of her old masters, in no case would she attempt such a course were it not for Russia. Hungary, Poland and other small countries of eastern Europe would be less inclined to forsake the ways of peace were it not for Russia, because their economic needs are so acute that they are extremely anxious to fit their policies to a general policy of reconstruction and rehabilitation.

The serious obstacle is Russia. American labor foresaw about what Genoa $^{1}$ would come to-and spoke its mind plainly. It is not in boastfulness that American labor says that it understands better than others what is the truth about Russia and what is

${ }^{1}$ This paper was written before the close of the Genoa Conference.-C. L. K. Editor. 
wrong in Russia. In the nature of things labor must understand.

American labor declared its position on Russia in 1920, reaffirmed it in 1921 and today stands by the declaration as originally made. It may be interesting to quote here a portion of the declaration made in 1920, when it was set forth:

That the American Federation of Labor is not justified in taking any action which could be construed as an assistance to, or approval of, the Soviet Government of Russia as long as that government is based upon authority which has not been vested in it by a popular representative national assemblage of the Russian people; or so long as it endeavors to create revolutions in the well-established, civilized nations of the world; or so long as it advocates and applies the militarization of labor and prevents the organizing and functioning of trade unions and the maintenance of a free press and frce public assemblage.

The purpose of American labor is twofold: first to protect American institutions; second to protect the Russian people.

"Destroy the American Federation of Labor," is the definite word that has gone out of Moscow to the Bolshevist propaganda machine in America. "Then destroy the American government."

As to the Russian people, for whom American labor has amply demonstrated its deep friendship, their danger is twofold: first, that the despotism may be strengthened and the enslavement of the Russian people, including Russian labor, be prolonged; second, that the despotism, thus strengthened, may barter for a pittance Russia's vast natural resources, making of Russia a great economic vassal, in pawn to foreign capitalists, carved into spheres of influence apportioned among foreign nations - a nation shorn of its wealth, bereft of its heritage, its people doomed to perpetual economic enslavement in addition to a hateful political enslavement which mocks at freedom and sneers at democracy.

What we witness at Genoa is a proposal that Russia's great natural wealth be exchanged for political recognition. Bear in mind the significance of political recognition: it validates what the despotism does, it legalizes the proposed barter and it gives foreign sanction to the domestic despotism as well.

\section{Political Recognition of BoLSHE'VISM}

We find many grave faults in our government, but we are happy to stand on this question in harmony with the policy laid down under the administrations of former President Wilson and of President Harding. The former laid down the great essential principles of human liberty, and under the latter, Secretary Hughes has laid down the great principles of international conduct upon which Americans insist.

American labor and the American government find themselves the protagonists of great world concepts which are exactly contrary to the course being pursued at Genoa. As a matter of fact, the policy which is coming to a head at Genoa is in every essential the policy which the European world has followed in dealing with China and with Turkey, and which it began to abandon in the Washington Conference where it was set up as a cardinal principle that henceforth China's economic independence must not be impaired. Secretary Hughes clearly stated that America at least holds to an identical principle in the case of Russia :

The resources of the Russian people should be free from exploitation and that 
fair and equal economic opportunity should be secured in their interest, as well as in the interest of all the powers.

One of the New York newspapers, supporting the idea of recognition of the Bolshevist government, is of the opinion that "the Russian problem is how to capitalize this future wealth of Russia in such a way as to finance a movement of trade from the overstocked west to the needy people of Russia."

I presume that statement represents a considerable amount of opinion, particularly among those primarily interested in what is called international finance. But it is not frank. The aim at Genoa is only incidentally to reach the needy people of Russia and America is doing more of that in the only way in which it can be done than all the rest of the world. What Genoa points to is a partnership between the Soviets and foreign capital for the mutual gain of both. American labor cannot feel that American industry, despite our great and acute industrial ills, will care to join in any such escapade. We have no right to look to the natural wealth of Russia as a reservoir out of which to rebuild any of our own industrial fortunes, nor has Europe a better right. No present international agreement for the entry of foreign capital into Russia can fail to work to the continued enslavement of the Russian people, or for the political debasement of every nation that enters into such an agreement. When the Russian people have found ther voice and can of their expressed will validate titles and policies it will be possible for the world to assist Russia without despoiling her and debasing itself.

Russia will gain no foreign credit by becoming the economic vassal of foreign states. Nor will America gain prosperity. Russia's potential credit is all that could be desired. To validate that credit she must set up political assets to match her economic assets and the world has a right to insist upon the establishment of those political assets because freedom is the essence of all of them.

The new military autocracy must go; the bureaucratic caste must go; the tremendously powerful Red army must go; there must be a restoration of freedom of press, of speech and of assemblage; there must be a government based upon consent and not upon repression; there must be justice and representation for all essential economic groups in Russian life. Then it will be possible to bring into full play the forces which will make for acceleration of American industrial life and for the full recovery of Russian industrial life. If, of their free will, the Russian people determine to maintain a form of government different from ours, they have that right and if they refuse to relieve themselves from their present bondage, they have that right; but we have the right to refuse relationship with whomsoever we will.

\section{America and Russia}

America is vitally concerned with how these things shall be adjusted. It is not because Americans will it that Russia, her internal affairs and her external relations, assume so large a place in their discussions and their fortunes. It is because Russia is so large a part of the world, because economically and politically she impinges upon the rest of the world and the rest of the world cannot move out of the way to avoid the shock.

I deem it essential, however, to make clear the belief of American labor in the proposition that, important though Russia is, America, more than any other nation, can be industrially prosperous in spite of the Russian fester that thrusts itself into every 
European consideration. We as a nation need not be in any large sense dependent for our industrial prosperity and well-being upon Europe, though of course it is impossible to escape from some of the effects of turbulence.

And there is this further proposition: American labor is not willing to determine every issue solely upon grounds of immediate and material consideration. It is unwilling to overlook the principle involved, even though that course may entail hardship. Labor is unwilling to urge a course in international relations that would do violence to principles which it deems essential to liberty the world over, even though such a course might result in immediate economic advantage. Better the longer road if that is the right road.

There is a tendency too frequently to overlook essential facts which I have tried to present, but which must be inadequately presented at best in any such limited space as I have at my disposal. The Bolshevik regime has made free labor an impossibility in Russia. It has destroyed the trade unions. It has destroyed the coöperatives. It has destroyed political parties opposed to the Bolshevik regime. There are in existence organizations called unions and coöperatives, but these organizations are mere painted substitutes for the originals, made to set before the world as window dressing and made to serve as Bolshevik agencies for the carrying out of orders. Free speech has disappeared. There is no free press and there is no freedom of assemblage. The massacre of the labor movement of Georgia is a classic example of Bolshevik policy in subjugated states, a Bolshevik pledge of tyranny wherever Bolshevik power is established. The Bolshevik threat against the American labor movement is direct and oft-expressed. The
American Federation of Labor stands intact today because American workers are too truly believers in democracy to wander in answer to the call of communism.

If our economic well-being were dependent upon a compromise with the hideousness of Bolshevism, then better that we suffer for a time. I do not know how well it is generally understood that you cannot compromise with Bolshevism; that you can only stand fast in opposition or surrender completely. It must be borne in mind that Bolshevism repudiates the entire code of ethics and morality of the democratic world. It recognizes no bond of faith in dealing with the world. It has always been a question, even in socialist organizations, whether the revolutionary movement was in any way bound to recognize what it called "capitalisl ethies," in other words, whether any revolutionary element was bound to keep a pledge to society or obey the laws of society. The more revolutionary the organization the more we have found the doctrine that "the only crime is in getting caught" and "the end justifies the means." Bolshevism recognizes no pledge to the outside world, except as something which may afford temporary advantage and as something to be broken when to break it means advantage. The honor that we know, the ethics that we know, the morality that we know-these things mean to Bolshevism only tools with which to undo the democratic world. We who observe the democratic code are the objects of scorn on the part of the Bolshevists who would undermine us while we stood bound to our agreement by the honor of a pledge made by us to be kept and by them to be broken.

That is why compromise is impossible; that is why democracy's economic and political safety lies in a strict ad- 
herence to our own principles and unyielding opposition to the fantasy of Bolshevism.

But we are not helpless without Europe, though we yearn for normal relations with the world for many reasons, not the least of which are sincerely altruistic.

\section{Abuses at Home}

Labor believes that our economic misery has been caused more by abuses at home than by complications abroad. We should have learned the lessons of coöperation in the War, and some did. But many powerful employers now tell us that there can be coöperation only between the employers and lone John Smith, the individual workman, standing by himself in a pitiful burlesque of bargaining with a milliondollar corporation. The organizations of the workers must go. They give strength, opportunity and something like equality of bargaining power to John Smith. So, behold, the misnamed open-shop movement, the American plan, libelling everything truly American, the whole anti-union movement to beat down wages, lengthen the workday and destroy working conditions secured after years of struggle. Behold also the waste, the mismanagement, the duplication, the literal looting of the channels of distribution, adding to the hardships of the workers, the farmers and that great portion of the population in the category of clerical workers and low paid professional workers.

We know that every dollar cut from wages and every dollar added to profit reduces the purchasing power of our people and results immediately in piling up surplus and this surplus shortly has its effect in shutting down mills and factories and destroying purchasing power.

I could have brought to you figures upon figures, but it seems to me a waste of time to seek to bulwark the obvious with figures which after all mean little in dealing with general principles.

We are dealing with major principles in our domestic economicand industrial life-and in our political life as well.

You may be sure the organizations of labor will continue to live and to grow, to plan constructively and to fight reaction and injustice. Without them, heaven help our country. With them in the hands of Lenine, breathe a prayer for the future! If these go, after them, not the flood, but the torch!

They hold within them much of the secret of restored industrial activity. They hold men who want to work. They hold men who will work and who, at work, will buy. Fair recognition of the aspirations of labor, fair dealing with labor, fair wages and conditions for labor, less of greed, less of the demand for twelve per cent, less of the rule or ruin policy among powerful employers and organizations of employers and we will be a happier people, a busier people, a people less driven to desperation by the desperation of Europe and more able to help Europe as Europe shall make that help possible.

But we cannot have that measure of domestic tranquillity and prosperity which is our due if those who hold industrial and financial power do not cure themselves of the million-dollar appetite, themillions habit. Four great national organizations of employers have broken contracts with wage earners in the past year; they have made scraps of paper out of their solemn pledges. How can we escape the effects of such breaches of faith? Powerful financial organizations throughout the country have practised almost unbelievable extortion in the building industry, extortion begetting extortion. Equally powerful organizations have beaten a path to 
the public treasury in Washington, where through the proposed ship subsidy, through the proposed tariff, through the railroad guaranty and the shop leasing and repair contract system, and through other equally amazing projects, they have taken and hope to take millions upon millions. We live in a time of extravagant dreams, which lead to practices of debauchery which cannot fail to reflect themselves in our general industrial life, to the detriment of the great body of frugal, toiling, honest and honorable people of our country.

So, what the American labor movement holds is that internationally we are fated more to give than to receive and that we stand ready to give where we can give as freemen to freemen, with honesty on both sides. We hope for an end to militarism, though that hope is dimmed by the Red army and by the alliance between Germany and the Bolshevist powers that rule the Red army. We believe that an essential to proper international economic rehabilitation is an international economic conference and there is little to be hoped for from any conference that is not primarily economic, such as the Genoa Conference.

\section{SUgGestions OF LABOR}

Labor makes bold to say that to achieve real success such a conference must be held in America in accordance with agenda made in America. This is not because we distrust others or feel a nation'al superiority, but because, happily, we are free from influences which surround European statesmen and enmesh European business. It will be well if in such an international economic conference political leaders may take a rank second to those who have their hands primarily on economic problems, the essential forces in industrial life.
We still have hope for the League of Nations. We see in every day's developments the great justification for the idea proffered by America in Paris and then struck down in America. Labor looks always with hope toward every effort, but hope and faith are not alike and labor has little faith in saving the world through occasional conferences of statesmen. If there can be held in America an economic conference that will give play to the economic forces of the world, that will bring them together, in open daylight, charged to work constructively, we may have something more than hope; we may have something of faith and the possibility is so great that labor urges, as it has urged from the first, that America summon such a conference, acting boldly as she did where limitation of armament was concerned.

Where our own national industrial prosperity is concerned we are constrained to look more closely to our own adjustments than to what may happen in international relationships. We see a nation beset with abuses, waste, strife and selfish ambition. If it is possible to apply remedies at home it will not be necessary to look to Europe for domestic prosperity. We may then lavish kindness and helpfulness upon Europe in some measure of repayment for the awful years through which Europe stemmed the tide of militarist destruction.

If we can stop idleness-not with unemployment conferences that arrive nowhere - but with essential readjustments in industry; if we can take some of the greed out of employers; if we can stop the wrongly called "normal" idleness, of which much more than four-fifths is due to causes other than strikes; if we can, as a nation, live the thought that workers are human beings, with human aspirations; if we can establish it as a national principle to be 
practised, that employers are to confer with workers, each side through representatives freely chosen; if we can keep predatory interests from disregarding every proper function and attribute of citizenship; if we can find a way to bring some fuller measure of justice to the farmer; if we can uproot from our life the idea that production is for profit alone and live up to the modern concept that production is primarily for use and for the progress of the human family and that no single section of the human family has a monopoly of the right to progress and to a constantly broadening horizon of service and happiness, then we shall be able, as a people and a nation, to beget in ample degree our own prosperity.

So long as we treat this as a bankers' world we are doomed to trouble and misery. When we see it as a people's world, we shall find ourselves and we shall wonder how it was that we ever had among us five millions who wanted to work, but who could find no work. 